\title{
Rising profile on the use of metal-organic frameworks (MOFs) for the removal of heavy metals from the environment: an overview
}

\author{
Hussein K. Okoro ${ }^{1} \cdot$ Stephen O. Ayika ${ }^{1} \cdot$ Jane C. Ngila ${ }^{3} \cdot$ Adedibu C. Tella $^{2}$
}

Received: 28 February 2018 / Accepted: 11 September 2018 / Published online: 21 September 2018

(c) The Author(s) 2018

\begin{abstract}
This review study is dealing with the recent advances and developments in the metal-organic framework (MOF) materials especially in the aspect of environmental remediation of heavy metals. Its application in some area of technological and mechanical advancement was also considered. The process of its synthesis and characterization was also put into consideration. Metal-organic frameworks can be said to be an exciting new class of nanoporous crystalline materials containing a metal as its central ion surrounded by organic ligands. An overwhelming characteristic of MOFs lies in its surface area which is amazingly large, exceeding those of known best activated carbons and zeolites. There is an increasingly high demand in the application of MOFs for a multitude of environmental uses or application to be used for capturing and separating various unwanted or even environmentally harmful chemicals, elements or materials. The advantage of MOFs over other known adsorbent materials, such as zeolites and carbon black, is that it possesses a far greater surface area along with amazingly great pore properties. In this review the synthesis and characterization of MOFs, the fate of heavy metals, the application of MOFs in heavy metals remediation and other means of heavy metals remediation are well discussed.
\end{abstract}

Keywords Metal-organic frameworks $\cdot$ Heavy metals $\cdot$ Environmental remediation

\section{Introduction}

MOFs were discovered almost two decades ago. They are a new class of micro- and mesoporous materials that possess framework flexibility and display enormously high surface areas with tunable pore size and functionality (Dey et al. 2015). MOFs are materials constructed from inorganic and organic building blocks, via the fundamental process of selfassembly at the molecular level. The synthesis of MOFs can be conventionally achieved by employing a synthetic

Hussein K. Okoro

okoroowo@yahoo.com; hkoadeola@gmail.com

1 Environmental-Analytical Research Group, Department of Industrial Chemistry, Faculty of Physical Sciences, University of Ilorin, P.M.B. 1515, Ilorin, Nigeria

2 Synthetic Inorganic and Materials Chemistry Research Laboratory, Department of Chemistry, Faculty of Physical Sciences, University of Ilorin, P.M.B. 1515, Ilorin, Nigeria

3 Analytical-Environmental and Membrane Nanotechnology Research Group, Department of Applied Chemistry, University of Johannesburg, P.O. Box 17011, Doornfontein, Johannesburg 2028, Republic of South Africa procedure wherein the metal ions and organic ligands are combined to form a crystalline, porous network. The resulting nanoporous materials encompass a myriad of 3D openframework structures, which feature various chemical and structural diversity (Cheetham et al. 2006). They are often crystalline, highly porous, and resistant to structural collapse upon evacuation. A large number of porous compounds with a large variety of characteristics, properties and applications had been successfully synthesized through the variation of the ligand character, functionality, spacer length, metal atom, and synthesis environment. Cantwell et al. (2015). The choice of metal and linker greatly determines the structure and hence properties of the MOFs synthesized. For example, the geometry or coordination preference of a metal affects greatly the size and shape of pores by influencing the number of ligands that can bind to the metal Sagar and Shah (2014).

Heavy metals can be found as natural constituents of the earth crust, and they have constituted a great number of environmental contaminants since they cannot be easily biodegraded or destroyed. They find their way into the human body system through food, air and water and bioaccumulate in the body over a period of time UNEP/GPA 
(2004). Heavy metals pollution has been identified as one of the leading problems in both terrestrial and aquatic environments. Heavy metals are serious environmental contaminants due to their toxicity, persistence in natural conditions and ability to be incorporated into the food chain and food web. The contamination of both terrestrial and aquatic systems by heavy metals, especially soils and sediments, has become one of the most challenging pollution issues owing to the toxicity, abundance, persistence and subsequent bioaccumulation of the heavy metals into the human body system (Okoro et al. 2017).

Wide range of techniques has been applied over the decades for removal of heavy metals from the environment. Heavy metals remediation therefore is a subject matter of high importance to human existence and environmental sustainability (Suparna and Anantharaman 2017).

The purpose of this review is to show how much applicable and how much work have been done in the utilization of these new set of amazing multifunctional compound in the aspect of environmental remediation of heavy metals and also its advances in some other aspects of human development. Furthermore, this article is to enlighten new researchers coming into this aspect of work what have been and what is still yet to be explored such that it will be attractive enough to them to enter this exciting research field, especially those aimed at materials scientists, engineers and technologists, who have some working knowledge and interests associated environmental remediation.

\section{Fate of heavy metals in the environment}

Heavy metals contaminants through the precipitation of their compounds or by ion exchange into soils and mud can localize and find their way into other environmental medium and ultimately into the human body. And unlike organic pollutants, heavy metals do not biodegrade and thus pose different kind of challenge for remediation (WHO 2011).

Okoro et al. (2015) reported a study of heavy metals concentration in the fingernail samples of young school children and selected adults with respect to their class, sex and age within Ilorin metropolis Kwara state. The work was carried out to establish the level of heavy metals $(\mathrm{Fe}$ and $\mathrm{Cu}$ ) and trace elements ( $\mathrm{Mg}$ and $\mathrm{K}$ ) present in the fingernails of young school children and some selected adults using the atomic absorption spectrophotometer method for metal analysis. Analysis of soil samples from an automobile workshop was also carried out to determine the level of heavy metals contamination. The result of the study showed presences of heavy metal in the fingernails of young school children and Adults in order of $\mathrm{Fe}>\mathrm{Cu}(0.43-6.85 \mu \mathrm{g} / \mathrm{g}, \mathrm{Cu}$ $0.01-0.08 \mu \mathrm{g} / \mathrm{g})$ and for essential trace metals $\mathrm{Mg}>\mathrm{K}(\mathrm{Mg}$ $0.47-1.97 \mu \mathrm{g} / \mathrm{g}, \mathrm{K} 0.25-1.32 \mu \mathrm{g} / \mathrm{g}$ ).
Okoro et al. (2012) reportedly carry out a study on the heavy metal presence in black mussels (Mytilus galloprovincialis) which was collected from Cape Town Harbour; this was determined using energy-dispersive $\mathrm{X}$-ray fluorescence (EDXRF) and inductively coupled plasma-mass spectrometry (ICP-MS). The tissue of the mussels was found to contain the following metals $\mathrm{K}, \mathrm{Ca}, \mathrm{Fe}, \mathrm{Cu}, \mathrm{Zn}, \mathrm{Si}, \mathrm{Sr}, \mathrm{Al}$ and $\mathrm{Au}$, while the shell portion was found to contained $\mathrm{K}, \mathrm{Ca}, \mathrm{Fe}$, $\mathrm{Cr}, \mathrm{Zn}, \mathrm{Si}$ and $\mathrm{Sr}$. The average metal concentrations reportedly found in the mussels are as follows $\mathrm{Pb}(7.30 \pm 0.67)$, $\mathrm{Cd}(1.98 \pm 0.13), \mathrm{Hg}(4.92 \pm 0.60)$, As $(6.94 \pm 0.04)$, Sn $(2.63 \pm 0.13), \mathrm{Ni}(1.88 \pm 0.05), \mathrm{Cr}(3.54 \pm 0.05), \mathrm{V}$ (4.17 \pm 0.23$)$, Co $(0.74 \pm 0.01)$ and $\mathrm{Mn}(35.20 \pm 1.46)$. Conclusively the average metal concentrations found in the mussels were higher than the permissible limits of Food and Agriculture Organization (FAO) and other international guidelines. More on the heavy metals mobility, seasonal variations of metals, etc., metals geochemical analysis in water and sediments has been carried by Okoro et al. (2012, 2013, 2014a, b) and Okoro and Jimoh (2016), respectively.

Ogoyi et al. (2011) reported the presence of trace metals from three different environmental samples (water, sediments and microalgae) which were sampled from Winam and Mwanza gulfs of the Lake Victoria. The results show that there were differences in trace metal concentration in water and microalgae between the Winam and Mwanza gulfs. At Winam Gulf, higher concentrations of the metallic elements were found in water samples than in microalgae samples while the Mwanza Gulf shows an opposite result with higher concentrations found in the microalgae than in water samples. In both gulfs, the heavy metal concentrations were found to be highest in the sediment samples. This shows that Lake Victoria basin has significant contamination levels but not as large as those of clearly polluted areas. However, there is need therefore for continuous monitoring of pollution levels in the lake.

\section{Synthesis and characterization of MOFs}

Metal-organic frameworks (MOFs) are synthesized mostly by the hydrothermal or solvothermal method, in which crystals are slowly grown from a hot solution. Contrary to zeolites, MOFs are developed from linking organic ligands that remain intact throughout the process of the synthesis with the metal atom (Cheetham et al. 1999). Zeolite on the other hand makes use of templates for their synthesis. Templates are ions that can influence the structure or geometry of the growing inorganic framework. Well-known templating ions are quaternary ammonium cations, which are usually removed after the process (Bucar et al. 2007). While in the synthesis of MOFs, the framework is templated by the SBU (secondary building unit) and the organic ligands (Parnham and Morris 2007). A templating procedure that is very useful 
for MOFs purposed to be used for gas storage is the use of metal-binding solvents such as $\mathrm{N}, \mathrm{N}$-diethyl formamide and water. In these occasions, metallic sites are exposed when the solvent is evacuated, giving room or space for hydrogen to bind at these sites (Dinca and Long 2008).

Synthesis of MOFs can also be done by combining organic ligands and metal salts in solvothermal processes at quite low temperatures (below $300{ }^{\circ} \mathrm{C}$ ). The properties of the ligand (bond angles, ligand length, bulkiness, chirality, etc.) play an important role in determining what the properties of the resultant framework will be (Férey et al. 2007). Also, the tendency of certain metal ions to take certain geometries when bonding also influences the structure of the MOFs. The reacting substances are mixed together in high boiling, polar solvents such as water, dialkyl formamides, dimethyl sulfoxide or acetonitrile (Ockwig et al. 2005). These parameters of solvothermal MOF synthesis which include temperature, the concentrations of metal salt and ligand (which can be varied across a large range), the extent of solubility (Tella et al. 2017a) of the reactants in the solvent, and the $\mathrm{pH}$ of the solution are very important and have a high level of influence on the MOFs (Zhao et al. 2008). Although experience largely dictates the best conditions for growing these crystalline frameworks, experimentation and trial-and-error procedures are still often necessary in some occasions. A number of works which gives procedure for the synthesis and characterization of MOFs have been previously published as well (Kitagawa et al. 2004; Kuppler et al. 2009) (Fig. 1).

Apart from this known synthesis method, a number of other synthetic procedures have been described in the literature which includes the mixture of non-miscible solvents, an electrochemical route and a high-throughput methodology (Mueller et al. 2006). Another promising and interesting synthesis pathway for MOFs is the microwave irradiation, which gives room to the use of wide range of temperatures, which can be used to shorten crystallization period while controlling face morphology and particle size distribution as well (Jhung et al. 2005). A serious factor limiting the use of this method is the lack of the formation of crystals of big sizes needed to obtain good structural data. Environmentally friendly solvent-free/mechanochemical synthetic methods have been reported by our group for the preparation of metal-organic frameworks and coordination polymers (Tella and Owalude 2014; Tella et al. 2014, 2015, 2017b, 2017c, 2018). Also of recent, the geometry of the SBU has been determined to be influenced not only the structure of the ligand and type of metal used, but also the ratio of the metal to ligand, the solvent, and the source of anions to balance the charge of the metal ion (Collins et al. 2008).

After the process of synthesizing, MOFs may be made to participate in or undergo further chemical process like other coordination polymers, to design or restructure the frameworks with molecules or/and functional groups in a process described as post-synthetic modification (PSM) (Wang and Cohen 2009). In some circumstances, the presence of a specific functional group on a ligand may prevent the formation of the desired MOFs. In this type of circumstance, it is ideal to initially prepare a MOF with the interested topology, and then add desired functional group to the framework (Batten et al. 2009). This approach can be used for MOFs that are prepared for catalysis and gas storage, as these uses require the presence of certain functional groups to reshape or influence the surface property and pore geometry of the synthesized MOF. It is worthy to note that the two most important points to note in PSM are making sure that the chemical reagent used to improve the functionality of the MOFs is small enough to fit inside the cavity of the MOF and the reaction conditions will not adversely affect the framework but rather enhance the formation of the desired MOF. If the reagent used is quite small to enter the cavity or the framework is adversely affected by the reaction, the whole process will be a total waste (Wang and Cohen 2009).

Tella and Owalude (2014) reported a new synthetic route of preparing MOFs which involves mixing of solid reactants, followed by heating. Two templated metal-organic frameworks (MOFs) were prepared using this method. $\left.\left[\mathrm{Ni}\left(\mathrm{NO}_{3}\right)_{2} \text { (bipy }\right)_{2}\right]$ (pyrene $)_{2}$ was obtained by mixing $\mathrm{Ni}\left(\mathrm{NO}_{3}\right) \cdot 26 \mathrm{H}_{2} \mathrm{O}, 4,4$-bipyridine and pyrene together and was heated at $85{ }^{\circ} \mathrm{C}$ for $4 \mathrm{~h}$. [ $\mathrm{Zn}_{2}$ (fumarate) ${ }_{2}$ (bipy)] was prepared by mixing $\mathrm{Zn}\left(\mathrm{O}_{2} \mathrm{CCH}_{3}\right) .22 \mathrm{H}_{2} \mathrm{O}$, fumaric acid and 4,4-bipyridine and heating at $160{ }^{\circ} \mathrm{C}$ for $16 \mathrm{~h}$ followed. The materials were then characterized using elemental analysis, FT-IR spectroscopy and X-ray powder diffraction analysis (XRPD). Thus this study suggests that MOFs can be synthesized in solid state simply by mixing together appropriate reactants. When compared with traditionally known synthetic techniques such as solvothermal, ball-milling and solution based, this synthesis pathway is more environmentally friendly and highly efficient in the manufacture of these MOFs on a large scale.

\section{Application of MOFs}

\section{Luminescence}

The hybrid and dynamic structure of MOFs materials, which include an organic ligand and a metal ion bonded in various geometry, allows a large number of emissive phenomena which can only be seen in few other types of materials, the conjugation and rigidity of the linkers aids the coordination of the central metal (Song et al. 2008). MOFs provide a dynamic platform for the production of solid-state luminescent materials as their structure have a high level predictive ability, apart from providing well-defined environments for lumophore which are in crystalline form (Sabbatini et al. 


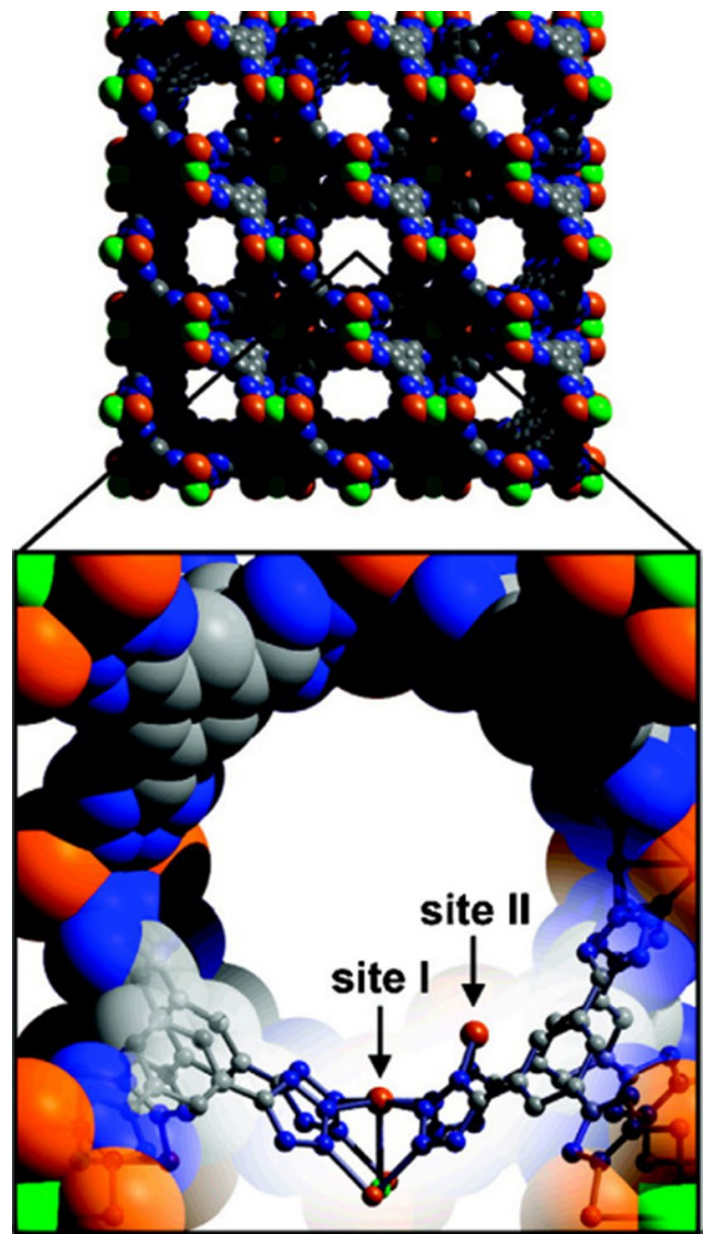

Fig. 1 Portion of a crystal structure showing two different types of $\mathrm{Mn}(\mathrm{II})$ sites exposed within its three-dimensional pore system of 10 $\AA$ wide channels. Site I is five coordinate, while site II is only two coordinate; the separation between them is 3.420(8) A. (Adapted from Kuppler et al. 2009)

1993). The lanthanoid ( $\mathrm{Ln}$ ) ions even in solution usually have narrow emission spectrally, and also a large number of the lanthanoids exhibit photoluminescent abilities (Richardson 1982). He et al. (2005), reportedly synthesized the first open-framework hetero-metallic MOFs structure based on the combination of infinite rod building units utilizing the solvothermal process of zinc nitrate hexahydrate, sodium hydroxide, and 1,3-benzene-dicarboxylic (m-BDC) acid. The high fluorescent emission of the above MOFs may make it a great potential and highly applicable photoactive material. Chen et al. (2008), reported a template luminescent MOFs $\mathrm{Tb}$ (BTC).G (MOF-76: $\mathrm{Tb}=$ Terbium, BTC = benzene-1,3,5-tricarboxylate, $\mathrm{G}=$ guest solvent), for the detection and sensing of some anions and it exhibits a high-sensitivity, detecting function with respect to fluoride ion. Such a detection process can be easily transformed into an external luminescence intensity change once luminescent metal site and/or organic linkers have been placed into the luminescent MOFs (Mahata et al. 2011).

\section{Magnetism}

Another known characteristic of metal-organic frameworks (MOFs) is magnetism (Day and Underhill 2000). This can be done by placing magnetic moment carriers like paramagnetic metals, open-shell organic ligands or both during the synthesis process (Itoh and Kinoshita 2000). MOFs that show magnetic properties and molecular magnets as well have been determined to be branches of coordination chemistry where metals are bound in a solid by coordination bonds to organic linkers which include their designs, synthetic procedure, methodology, structures, and physical properties (Davis 2002). Lanthanoids, due to their high spin numbers and highly magnetic anisotropies on the $4 \mathrm{f}$ orbitals they possess, are attractive as magnetic materials (Maspoch et al. 2007). Liu et al. (2008), reportedly prepared a high nuclearity cubic cage containing $64 \mathrm{Fe}^{3+}$ ions that show a high level of anti-ferromagnetism. They also show that the combination of the small stereo-hindrance $\mathrm{HCOO}^{-}$and polypodal ligands can give high nuclearity magnetic clusters.

\section{Gas storage}

\section{Hydrogen gas}

The $\mathrm{Zn}_{4} \mathrm{O}(\mathrm{BDC})_{3}$, a cubic carboxylate-based framework which was one the earliest metal-organic frameworks attempted for hydrogen gas storage and its gas storage ability was discovered to based mainly on the methods used for the synthesis, characterization and activation. It has Langmuir surface areas that range between 1010 and $4400 \mathrm{~m}^{2} \mathrm{~g}^{-1}$, and its $\mathrm{H}_{2}$ storage ability varies accordingly (Kaye et al. 2007). Rowsell et al. (2005) reported remarkably a more in-depth details about the primary binding sites of hydrogen gas on a number of metal-organic frameworks which has $\mathrm{Zn}_{4} \mathrm{O}\left(\mathrm{O}_{2} \mathrm{C}\right)_{6}$ secondary building units as well as an inelastic neutron which scatters because the adsorbed molecules cannot rotate (Fig. 2).

\section{Methane gas}

Compressed natural gas (CNG) has been known to provide about $26 \%$ of the quantitative energy density of gasoline which usually act at high pressures around 200 bar because it has to be compressed. Also, adsorbed natural gas (ANG) as well gives an alternative storage means where the NG is adsorbed onto a porous adsorbent, ANG (at $500 \mathrm{psig}$ ) has been reported to have about $80 \%$ volumetric storage energy density compared to CNG (at 3000 psig) (Menon and Komarneni 1998). Kondo et al., reportedly was the 


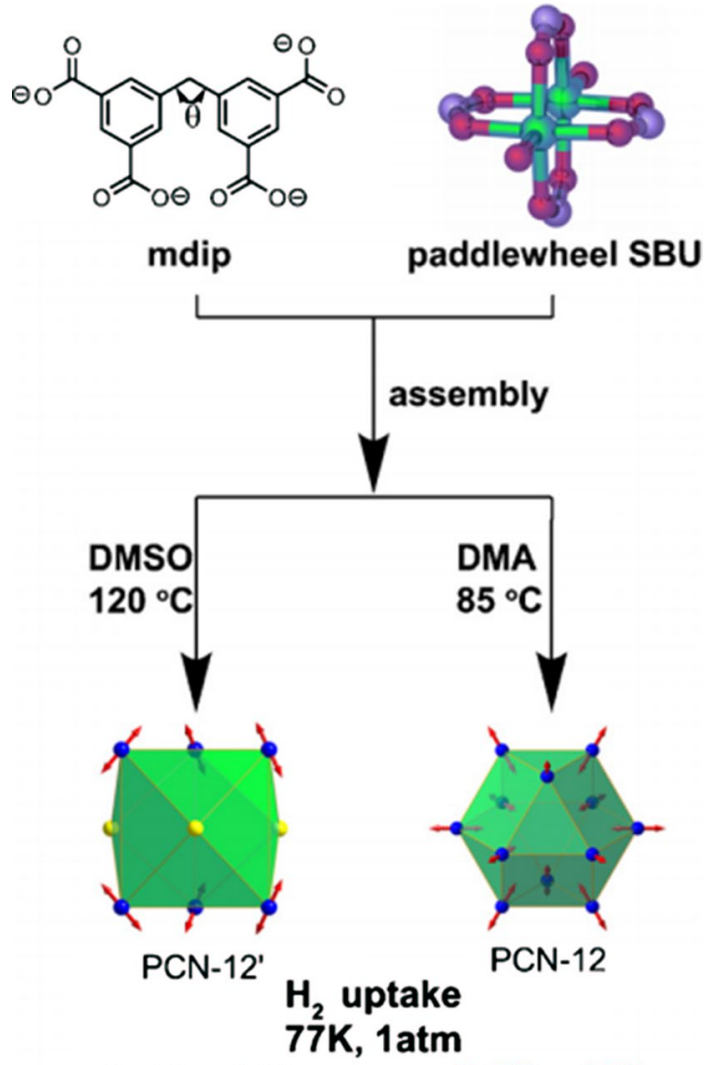

2.40 wt \%

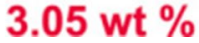

Fig. 2 Synthesis, UMCs alignment, and hydrogen uptake of two MOF poly-morphs: PCN-12 and PCN-12' (Adapted from Kuppler et al. 2009)

first to make use of MOFs for the adsorption of methane. The summary of their study shows the surface area, porosity and methane uptake data of some certain MOFs. Ma et al. (2012a, 2012b) in a report showed that the methane uptake in a MOFs can exceed the United States Department of Energy target which can be said to be the breakthrough in the study of use of MOFs for methane gas storage. The MOFs crystallographic density is one point to note as methane gas uptake data calculation was found to be based on it, it is larger than the packing density of the MOFs due to the empty space created by the particle packing. Methane gas uptake data need more work to be done to determine MOFs real packing density from the MOFs in order to determine the ability of MOFs in methane gas storage (Senkovska and Kaskel 2008).

\section{Gas adsorption and separation}

In industrial process, adsorptive removal, isolation or separation requires efficient porous materials, prepared as traditional porous solid material (Mueller et al. 2006). The porous metal-organic frameworks with their tailored structures and tunable surface characteristics are now suitable materials for gas adsorption and separations; they have also proven to be thermally stabile; most of the time, their structures are large enough to suit the removal of some guest species that leads to permanent porosity, so MOFs can be said to be suitable for research and practical applications in gas separation and purification as adsorbents for industrial utilization (Yang et al. 2012). An et al. 2010 synthesized a porous MOFs $\mathrm{Co}_{2}(\mathrm{ad})_{2}\left(\mathrm{CO}_{2} \mathrm{CH}_{3}\right)_{2}$. DMF-0.5 $\mathrm{H}_{2} \mathrm{O}$ (bioMOF-11) through solvothermal method of synthesis using cobalt acetate tetrahydrate and adenine in DMF; this has a high thermal capacity for adsorption of $\mathrm{CO}_{2}$, high $\mathrm{CO}_{2}$ capacity, and high preference for adsorption of $\mathrm{CO}_{2}$ over $\mathrm{N}_{2}$. Britt et al. 2009 reported an already in use MOF, MgMOF-74, which has open magnesium sites, which significantly compete with adsorbents in $\mathrm{CO}_{2}$ adsorption, with 8.9 wt. \% dynamic capacity; it has the ability to release adsorbed $\mathrm{CO}_{2}$ at significantly lower temperature of $80{ }^{\circ} \mathrm{C}$. The Mg-MOF-74 provides an amazing ability to adsorb and release the adsorbed material. This report shows that MOFs with open metal sites have great ability to be excellent $\mathrm{CO}_{2}$ adsorbent or storage materials.

\section{Drug delivery}

The inefficiency of delivering medication at a controlled release rate by drugs administered by the known oral method of drug delivery has increased the interest and research into other novel methods of delivering drugs. Known ways of delivering drug are polymeric-based systems, liposomebased systems, microporous zeolites, mesoporous silicon, and other mesoporous materials (Rimoli et al. 2008). Tella et al. (2017a, b, c, d) reported the application of Zinc fumarate and copper isonicotinate MOFs for loading of ibuprofen and urea. Zinc fumarate exhibited a very high drug loading capacity of $98 \%$ wt ibuprofen, while copper isonicotinate exhibited slightly high loading capacity of $44 \%$ wt of urea. Loiseau et al. 2004 reported the drug-delivering rate of a MOF MIL-53, which is a flexible material known for its capacity to increase the size of its morphology which is known as breathing effect. MIL-53 has volumetric capacity of about $1500 \AA 3$ at high temperature, and full expansion, it took up about $20 \mathrm{wt} \%$ of ibuprofen with a full and total delivery of the drug took about three weeks (Horcajada et al. 2008). The flexibility of the framework attributed for its ability of a long and stable delivery of the drug, which helps in bending the ibuprofen molecules around to maximize the bonding interactions while still minimizing steric hindrance (Horcajada et al. 2008).

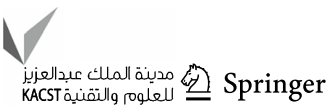




\section{Use of MOFs for remediation of heavy metals}

Shooto et al. 2015 reported the application of the two MOFs namely Copper and Cobalt 1, 2, 4, 5-tetrabenzene carboxylates. The adsorption capacity of the $\mathrm{Cu}-\mathrm{MOF}$ for removal of heavy metals was higher than that of Co-MOF, indicating that $\mathrm{Cu}-\mathrm{MOF}$ was a better adsorbent than $\mathrm{Co}-\mathrm{MOF}$. The characterization results were obtained from scanning electron microscopy, energy-dispersive X-ray, thermogravimetric analysis and X-ray diffraction spectroscopy. The morphological features of the copper- and cobalt-MOFs showed that it was a highly crystalline material which was also confirmed by the SEM micrographs. The EDX spectra of the two metal-organic frameworks show that $\mathrm{C}, \mathrm{O}$ and $\mathrm{OH}$ are present which aids in the creation of charges and functionalities on the surface of the metal-organic frameworks for adsorption. The isotherm batch adsorption experiment and thermodynamic equilibrium were carried out to determine the effect of concentration, time and temperature on the adsorption process. The results obtained showed that $\mathrm{Cu}-\mathrm{MOF}$ were better adsorbent than Co-MOFs.

Wu et al. 2012 prepared a polystyrene (PS) nanofibrous materials using electrospinning process, which was then used as a template for thiol-functionalized mesoporous silica material. A macroporous structures (diameters of 3-10 $\mu \mathrm{m}$ ) were found in the structure of the PS nanofibers which was randomly distributed in the membrane. The optimum $\mathrm{pH}$ for the adsorption of $\mathrm{Cu}^{2+}$ was around 5, and the qmax value obtained was $11.33 \mathrm{mg} / \mathrm{g}$. $\mathrm{Cu}^{2+}$ ions were adsorbed by $-\mathrm{SH}$ groups within the mesopores. The adsorbent was determined to contain $0.32 \mathrm{mmol} / \mathrm{g}$ of thiol group, and the adsorption efficiency $\left(\mathrm{Cu}^{2+} / \mathrm{SH}\right.$ molar ratio) of the adsorbent was found to be about $80 \%$. The adsorptive strength capacity of the $\mathrm{Cu}^{2+}$ was practically retained after five cycles; the adsorbent was recovered using $0.5 \mathrm{M} \mathrm{HCl}$,

Ma et al. (2012a, b) reportedly carry out an adsorption experiments on the adsorptive strength of $\mathrm{CaCO}_{3}$-pepsin for $\mathrm{Pb}^{2+}$ and $\mathrm{Cu}^{2+}$ using neutral $\mathrm{pH}$ environment and the adsorptive strength of $\mathrm{CaCO}_{3}$-pepsin for $\mathrm{Pb}^{2+}$ and $\mathrm{Cu}^{2+}$ was determined to be 1167 and $611 \mathrm{mg} / \mathrm{g}$, respectively, while the adsorption of $\mathrm{Pb}^{2+}$ was faster (about $20 \mathrm{~min}$ ). Solution yield of $\mathrm{PbCO}_{3}$ and $\mathrm{CuCO}_{3}$ was lower when compared to $\mathrm{CaCO}_{3}$ showing that $\mathrm{Cu}^{2+}$ and $\mathrm{Pb}^{2+}$ precipitate as their carbonates.

Ma et al. (2012a, b) also carried out the adsorptive capabilities of $\mathrm{CaCO}_{3}$-maltose which is a hierarchical structure super-adsorbent, for $\mathrm{Pb}^{2+}, \mathrm{Ni}^{2+}, \mathrm{Cu}^{2+}$ and $\mathrm{Cd}^{2+}$ (as metal carbonate) which were determined to be $3242.48,769.23$, 628.93 and $487.8 \mathrm{mg} / \mathrm{g}$, respectively, whereas adsorptive capability of $\mathrm{CaCO} 3$ for $\mathrm{Pb}^{2+}$ is $62.5 \mathrm{mg} / \mathrm{g}$ which indicates a good synergic effects between organic and inorganic moieties that exist in these compounds. These organic-inorganic hierarchically structured compounds can be said to be superadsorbents from the results gotten.
Tella et al. (2007) reported the adsorption of $\mathrm{Pb}(\mathrm{II})$, $\mathrm{Cd}(\mathrm{II}), \mathrm{Zn}(\mathrm{II}), \mathrm{Cu}$ (II) and $\mathrm{Hg}$ (II) metals ions from their respective aqueous solution using formaldehyde and pyridine-modified bean husks as the adsorbents. The adsorptive strength of the formaldehyde-modified bean husks $(\mathrm{mg} / \mathrm{g}$ ) was found to be as follows: $\mathrm{Pb}^{2+}, 5.01 ; \mathrm{Cd}^{2+}, 3.63 ; \mathrm{Zn}^{2+}$, $2.18 ; \mathrm{Hg}^{2+}, 1.82 ; \mathrm{Cu}^{2+}, 1.58$, while the pyridine-modified bean husk was found to be as follows: $\mathrm{Hg}^{2+}, 6.92 ; \mathrm{Cd}^{2+}$, $3.63 ; \mathrm{Pb}^{2+}, 2.64 ; \mathrm{Zn}^{2+}, 2.48 ; \mathrm{Cu}^{2+}, 1.91$. From the evaluated figures of Freundlich adsorption parameter (KF) and Langmuir adsorption parameter (qmax), it was determined that the adsorptive capabilities of these metal ions were in the order of $\mathrm{Pb}^{2+}>\mathrm{Cd}^{2+}>\mathrm{Zn}^{2+}>\mathrm{Hg}^{2+}>\mathrm{Cu}^{2+}$ for formaldehyde-modified bean husks and $\mathrm{Hg}^{2+}>\mathrm{Cd}^{2+}>\mathrm{Pb}^{2+}>\mathrm{Zn}^{2+}>\mathrm{Cu}^{2+}$ for pyridine-modified bean husks.

\section{Other conventional method for heavy metals removal from environmental samples}

\section{Activated carbon}

Activated carbon can be said to be a non-selective adsorbent that adsorbs virtually all the natural organic materials which are found in waters which leads to a decline in its ability to accumulate or adsorb toxic organics (Ilisz et al. 2002). Activated carbon is described as a wide range of amorphous carbon based materials designed to possess a high level of porosity and an extended inter-particulate surface area (Bansal et al. 1988). These characteristics equip the activated carbon with excellent adsorbent capabilities and it is basically defined more or less by its properties rather than its sources, as it can be prepared from a large number of carbon-rich raw materials that can be of animal, mineral or agricultural wastes origins (Austin 1987), which maybe include tree, peat, coal, bones, coconut shells and fruit stones. Activated carbon prepared from coconut coir pith has been determined to efficient for the treatment of wastewater as well for the adsorption of $\mathrm{As}, \mathrm{Cu}, \mathrm{Hg}, \mathrm{Ni}$ and organics from aqueous solution (Namasivayam and Kardirverlu 1998). Activated carbons produced using rice husk and coconut husk and sawdust have been used for the treatment of wastewater on various occasions (Raji et al. 1997).

Kermani et al. (2006) also revealed from their study that rice husk ash as well as its granular activated carbon is efficient and good adsorptive material for the adsorption of phenol from aqueous solution. Its correlation to the Freundlich and Langmuir adsorption models to the equilibrium data was also determined on each phenolsorbent system. The reported data for the rice husk ashes that were prepared at 400 and $500{ }^{\circ} \mathrm{C}$ as well as that of the granular activated carbon fitted perfectly well into the Freundlich isotherm model while the rice husk ash that 
was produced at $300{ }^{\circ} \mathrm{C}$ was found to correlate with the Langmuir isotherm model.

\section{Chicken feather}

Aguayo-Villarreal et al. (2011) reported the use of raw chicken feathers for the adsorption of zinc ions from aqueous solution employing batch and continuous adsorptive methods. The effect of temperature, $\mathrm{pH}$ and metal concentration was determined using kinetic and sorption isotherms. The data obtained from the batch adsorption process were placed into various adsorption models, and results show that $\mathrm{Zn}^{2+}$ metal ion adsorption process using raw chicken feathers followed the pseudo-second-order rate model, the sorption isotherms were explained in details using Sips isotherm. The experimental maximum adsorption capability of $\mathrm{Zn}^{2+}$ ion was determined to be $4.31 \mathrm{mg} / \mathrm{g}$ at $30{ }^{\circ} \mathrm{C}$ and $\mathrm{pH} 5$ as shown by the adsorption isotherms and that chemisorption might have play a great role in the procedure. The curves obtained for variation of the adsorption experimental conditions of the $\mathrm{Zn}^{2+}$ metal ions using a fixed-bed column packed with raw chicken feather were perfect. Results obtained indicate that the characteristics of these breakthrough curves are dependent of the column operating conditions, especially $\mathrm{pH}$ and feed flow rate. Thomas model was used for data fitting of adsorption continuous experiments and for determining design parameters useful to characterize the performance of packed bed columns. The results obtained show that raw chicken feathers are a potential low cost adsorbent of $\mathrm{Zn}^{2+}$ metal ions from aqueous solutions.

\section{Mud}

Mobasherpour et al. (2014) studied the adsorption of lead ion form aqueous solution using red mud as adsorbent applying batch and fixed-bed column adsorption methods. An equilibrium time of $2 \mathrm{~h}$ was obtained experimentally in the batch process. The results obtained fitted well into the Langmuir adsorption isotherm, and the adsorption strength of the mud was determined to be $18.87 \mathrm{mg} / \mathrm{g}$. The experimental conditions for the fixed-bed process included different influent lead concentrations, bed depths and flow rates. The optimum adsorption time and exhaustion time decreased as the flow rate increases, as the bed depth decreases and lead concentration increases. The bed depth service time model and the Thomas model were used to treat the experimental data obtained. The predictions of the models were in correlation with the results obtained from the experiment for all the process parameters under consideration; this shows that the models were appropriate for the red mud fixed-bed column design.

\section{Toxicology effects of MOFs on the environment}

The toxicological effects of both the bulk and nanoscale MOFs is yet to be fully discovered. It is a known fact that size of a material is an essential point of consideration when determining its toxicological characteristics, as the size of a substance affects the rate at which cells will absorb it, its bio-distribution, its ability translocate and its removal from the body. A decrease in the size of a substance will lead to an increase in its surface to volume ratio; thus, such substance becomes more reactive. A number of reports have shown that the cytotoxicity and translocation of nano-particles depend on the size of such materials (Sajid et al. 2015). However, it is important to note that some statements available show the non-toxicity of these interesting compounds. The nano-ZIF-8 $(200 \mathrm{~nm})$ for instance was researched with three human cell lines (mucoepidermoid carcinoma of lung [NCI-H292], colorectal adenocarcinoma [HT-29], and promyelocytic leukemia [HL-60]); the obtained results show that the nano-ZIF does not show any toxicity even at the highest tested concentration $(109 \mu \mathrm{M})$ (Vasconcelos et al. 2012). But it is worthy to note that some contradiction occurs, the $-8(90 \mathrm{~nm})$ in a different work was observed to have cytotoxicity to Hela and J774 cell lines; the IC50 values of 436 and $109 \mu \mathrm{M}$ were obtained for the Hela and J774, respectively (Tamames-Tabar et al. 2014).

Ruyra et al. (2015) worked on an uncoated nanoscale MOFs which was tested for its vitro toxic effects on the HepG2 and MCF7 cells, as well as its in vivo toxic effects on the zebra-fish embryos. The results obtained from the work show that the toxic effect of this nanoscale MOFs is determined by the nature of the MOF and the ability of its contents to be soluble in the medium be used for the test. The in vitro and in vivo toxic effect of the MOFs was found to have a high level of correlation. Its toxicological effects were found to be due to some leached metal ions. The formation of new species upon degradation, nature of crystals (e.g., size, shape, charge) concluded may contribute to the toxicological effects of nanoscale MOFs. Occupational exposure which is most likely to occur during the synthesis, characterization, packaging, transportation, and applications of these materials is still the major source of exposure to these materials by human. Therefore, dermal penetration, inhalation and ingestion are still the most likely route for these materials to get into the human body. Exposure to these materials occupationally can be reduced to a large degree by adopting good lab practices which include the use of special personal safety equipment and proper control of working environment. The personnel exposed to these materials should be tested periodically for possible health risks related to handling these materials; the working environment should be monitored regularly (Sajid 2016).

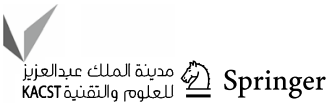




\section{Conclusion}

Metal-organic frameworks have distinctively been discovered from works done to be interesting materials with a large scope of applications ranging from drug delivery to gas storage to environmental remediation. They have been proven to be eco-friendly from their synthetic pathway to their application. Works done so far on its toxicity as well shows that they are less toxic when compared with other known synthetic materials. Metal-organic frameworks are good remediation materials as they are easily synthesized, eco-friendly during application, high adsorption capacity, easy regeneration and re-usability.

Acknowledgements The authors Dr HK Okoro and Prof JC Ngila thank UJ Global Excellence and Stature Scholarship for running cost paid by Water Research Commission WRC Project No. K5/2365. Dr. A.C. Tella is grateful to the Royal Society of Chemistry, UK, for the award of 2016 research fund. The Authors also thank University of Ilorin, Ilorin, Nigeria, and University of Johannesburg, South Africa, for making available the library database and Laboratory facilities.

Open Access This article is distributed under the terms of the Creative Commons Attribution 4.0 International License (http://creativeco mmons.org/licenses/by/4.0/), which permits unrestricted use, distribution, and reproduction in any medium, provided you give appropriate credit to the original author(s) and the source, provide a link to the Creative Commons license, and indicate if changes were made.

\section{References}

Aguayo-Villarreal IA, Bonilla-Petriciolet A, Hernández-Montoya V, Montes-Moránc MA, Reynel-Avila HE (2011) Batch and column studies of $\mathrm{Zn}^{2+}$ removal from aqueous solution using chicken feathers as sorbents. Chem Eng J 167(2011):67-76

An J, Geib SJ, Rosi NL (2010) High and selective CO2 uptake in a cobalt adeninate metal-organic framework exhibiting pyrimidineand amino-decorated pores. J Am Chem Soc 132(1):38-39

Austin OK (1987). Commercial manufacture of carbon black in reinforcement of elastomers 5th edn. Chapter 5. Wiley, New York, pp 20-50

Bansal RC, Jean-Baptiste D, Fritz S (1988) Active carbon. Marcel Dekker Inc., New York

Batten SR, Neville SM, Turner DR (2009) Coordination polymers: design, analysis and application. Royal Society of Chemistry, Cambridge, $\mathrm{p} 471$

Britt D, Furukawa H, Wang B, Glover TG, Yaghi OM (2009) Highly efficient separation of carbon dioxide by a metal-organic framework replete with open metal sites. Proc Natl Acad Sci USA 106(49):20637-20640

Bucar DK, Papaefstathiou GS, Hamilton TD, Chu QL, Georgiev LR, MacGillivray LR (2007) Template-controlled reactivity in the organic solid state by principles of coordination-driven selfassembly. Eur J Inorg Chem 2007(29):4559-4568

Cantwell CD, Moxey D, Comerford A, Bolis A, Rocco G, Mengaldo G et al (2015) Nektar++: an open-source spectral/hp element framework. Comput Phys Comm 192:205-219

Cheetham AK, Férey G, Loiseau T (1999) Open-framework inorganic materials. Angewandte Chemie Int Edit 38(22):3268-3292
Cheetham AK, Rao CN, Feller RK (2006) Structural diversity and chemical trends in hybrid inorganic-organic framework materials. RSC Chem Commun. https://doi.org/10.1039/b610264f

Chen B, Wang L, Zapata F, Qian G, Lobkovsky EB (2008) A luminescent microporous metal-organic framework for the recognition and sensing of anions. J Am Chem Soc 130(21):6718-6719

Collins CS, Sun D, Liu W, Zuo J-L, Zhou H-C (2008) Reactioncondition-controlled formation of secondary-building-units in three cadmium metal-organic frameworks with an orthogonal tetrakis (tetrazolate) ligand. J Mol Struct 890:163. https://doi. org/10.1016/j.molstruc.2008.04.038

Davis ME (2002) Ordered porous materials for emerging applications. Nature 417(6891):813-821. https://doi.org/10.1038/nature00785

Day P, Underhill AE (eds) (2000) Metal-organic and organic molecular magnets, vol 252. Royal Society of Chemistry, Cambridge

Dey SS, Kind J, Pagie L, de Vries SS, Nahidiazar L, Bienko M, Zhan Y (2015) Genome-wide maps of nuclear lamina interactions in single human cells. Cell 163(1):134-147

Dinca M, Long JR (2008) Hydrogen storage in micro porous metalorganic frameworks with exposed metal sites. Angew Chem Int Ed 47(36):6766-6779

Férey G, Cejka J, van Bekkum H, Corma A, Schüth F (2007) Ordered porous solids: recent advances and prospects. Stud Surf Sci Catal 168(49):327-374

He J, Yu J, Zhang Y, Pan Q, Xu R (2005) Synthesis, structure and luminescent property of a heterometallic metal-organic framework constructed from rod-shaped secondary building blocks. Inorg Chem 44(25):9279-9928

Horcajada P, Serre C, Maurin G, Ramsahye NA, Balas F, ValletRegi M, Sebban M, Taulelle F, Férey G (2008) Flexible porous metal-organic frameworks for a controlled drug delivery. J Am Chem Soc 130(21):6774-6800. https://doi.org/10.1021/ja710 $973 \mathrm{k}$

Ilisz I, Dombi A, Mogyorosi K, Farkas A, Dekany I (2002) Removal of 2-chloropheneol from water by adsorption combined with TiO2 Photo catalysis. Appl Catal B 1214:1-10

Itoh K, Kinoshita M (eds) (2000) Molecular magnetism: new magnetic materials. Gordon Breach-Kodansha, Tokyo

Jhung SH, Yoon JW, Hwang J-S, Cheetham AK, Chang J-S (2005) facile synthesis of nanoporous nickel phosphates with organic templates under microwave irradiation. Chem Mater 17(17):4455-4460. https://doi.org/10.1021/cm047708m

Kaye SS, Dailly A, Yaghi OM, Long JR (2007) Impact of preparation and handling on the hydrogen storage properties of $\mathrm{Zn} 4 \mathrm{O}(1,4-$-benzenedicarboxylate)3 (MOF-5). J Am Chem Soc 129(46):14176-14177

Kermani M, Pourmoghaddas H, Bina B, Khazaei Z (2006) Removal of phenol from aqueous solutions by rice husk and activated carbon. Pak J Biol Sci 9(10):1905-1910

Kitagawa S, Kitaura R, Noro S (2004) Functional porous coordination polymers. Angew Chem Int Ed Engl 43(18):2334-2375. https://doi.org/10.1002/anie200300610

Kuppler RJ, Timmons DJ, Fang Q-R, Li J-R, Makal TA, Younga MD, Yuan D, Zhao D, Zhuang W, Zhou H-C (2009), Potential applications of metal-organic frameworks. Coord Chem Rev 253:3042-3066. www.elsevier.com/locate/ccr

Liu T, Zhang J, Wang ZM, Gao S (2008) A 64-nuclear cubic cage incorporating propeller-like FeIII8 apices and $\mathrm{HCOO}^{-}$edges. $\mathrm{J}$ Am Chem Soc 130(32):10500-10501

Loiseau T, Serre C, Huguenard C, Fink G, Taulelle F, Henry M, Bataille T, Férey G (2004) A rationale for the large breathing of the porous aluminum terephthalate (MIL-53) upon hydration. Chem Eur J 10:1373-1382. https://doi.org/10.1002/chem.20030 5413

Ma X, Li L, Yang L, Su C, Wang K, Jiang K (2012a) Preparation of hybrid $\mathrm{CaCO} 3$-pepsin hemisphere with ordered hierarchical 
structure and the application for removal of heavy metal ions. J Cryst Growth 338:272-279

Ma X, Li L, Yang L, Su C, Wang K, Yuan S, Zhou J (2012b) Adsorption of heavy metal ions using hierarchical $\mathrm{CaCO} 3$-maltose meso/ macroporous hybrid materials: adsorption isotherms and kinetic studies. J Hazard Mater 209-210:467-477

Mahata SK, Lu M, Sarruf DA, Talukdar S, Sharma S, Li P, Bandyopadhyay G, Nalbandian S, Fan W, Gayen JR, Webster NJ (2011) Brain PPAR- $\gamma$ promotes obesity and is required for the insulin-sensitizing effect of thiazolidinediones. Nat Med 17(5):618

Maspoch D, Ruiz-Molina D, Veciana J (2007) Old materials with new tricks: multifunctional open-framework materials. Chem Soc Rev 36(5):770-818

Menon V, Komarneni S (1998) J Porous Mater 5:43. Print ISSN 13802224 Online ISSN 1573-4854. https://doi.org/10.1023/A:10096 73830619

Mobasherpour I, Salahi E, Asjodi A (2014) Research on the batch and fixed-bed column performance of red mud adsorbents for lead removal. Can Chem Trans 2(1):83-96

Mueller U, Schubert M, Teich F, Puetter H, Schierle-Arndt K, Pastr' e J (2006) Metal-organic frameworks-prospective industrial applications. J Mater Chem 16(7):626-636

Namasivayam C, Kardirverlu K (1998) Carbonised coirpith as adsorbent for the removal of toxic ions, dyes and pesticides from wastewaters. Indian J Chem Technol 5:334-336

Ockwig NW, Delgado-Friedrichs O, O'Keeffe M, Yaghi OM (2005) Reticular chemistry: occurrence and taxonomy of nets and grammar for the design of frameworks. Acc Chem Res 38(3):176-182. https://doi.org/10.1021/ar0200221

Ogoyi DO, Mwita C, Shiundu PM, Nguu EK (2011) Determination of heavy metal content in water, sediment and microalgae from Lake Victoria, East Africa. Open Environ Eng J 4:156-161

Okoro HK, Jimoh HA (2016) Speciation and determination of priority metals in sediments of Oyun River, Ilorin, Kwara, Nigeria. Bull Chem Soc Ethiop 30(2):199-208. https://doi.org/10.4314/bcse. v30i2.4

Okoro HK, Fatoki OS, Adekola FA, Ximba BJ, Snyman RG (2012) Bioaccumulation of metals in black mussels (Mytilus galloprovincialis) in Cape Town Harbour, South Africa. Environmentalist 32:48-57. https://doi.org/10.1007/s10669-011-9370-5

Okoro HK, Fatoki OS, Adekola FA, Ximba BJ, Snyman RG (2013) Physico-chemical characteristics and One year monitoring of heavy metal pollution in Seawater from Cape Town Harbour and their Seasonal Variation. Fresenius Environ Bull Ger. 22(10); 2855-2866. Published by Parlar Scientific Publication Freising, Germany. https://www.researchgate.net/.../275351493

Okoro HK, Fatoki OS, Adekola FA, Ximba BJ, Snyman RG (2014) Geochemical assessment of sediment in Cape Town Harbour, South Africa. Bull Chem Soc Ethiop 28(1):17-28. Published by Ethiopia Chemical Society of Ethiopia. Addis Ababa. http://www. ajol.info.index.php/bcse

Okoro HK, Fatoki OS, Adekola FA, Ximba BJ, Snyman RG (2014) Fractionation, mobility and multivariate statistical evaluation of heavy metals in marine sediments of Cape Town Harbour. Chem Speciat Bioavailab St Albans Herts UK 26(3):126-138, Published by Science Reviews 2000 Ltd. http://www.sciencereviewa2000. co.uk/index.php. Acceptance letter dated. 06 May 2014

Okoro HK, Alao ST, Adebayo GB, Basheer KA (2015) Evaluation of heavy and trace metals in fingernails of young school children and adults in Ilorin, Kwara State, Nigeria. J Appl Sci Environ Manag 19(2):319-324. www.bioline.org.br/ja

Okoro HK, Ige JO, Iyiola OA, Ngila JC (2017) Fractionation profile, mobility patterns and correlations of heavy metals in estuary sediments from olonkoro river, in tede catchment of western region,
Nigeria. Environ Nanotechnol Monit Manag 8:53-62. https://doi. org/10.1016/j.enmm.2017.04.003

Parnham ER, Morris RE (2007) Ionothermal synthesis of zeolites, metal-organic frameworks, and inorganic-organic hybrids. Acc Chem Res 40(10):1005-1013

Raji C, Manju GN, Anirhudhan TS (1997) Chromium (VII) adsorption by sawdust carbon: kinetics and equilibrium. Indian J Chem Technol 4:228-236

Richardson FS (1982) Terbium(III) and europium(III) ions as luminescent probes and stains for bio-molecular systems. Chem Rev 82(5):541-552

Rimoli MG, Rabaioli MR, Melisi D, Curcio A, Mondello S, Mirabelli R, Abignente E (2008) Synthetic zeolites as a new tool for drug delivery. J Biomed Mater Res Part A 87A(1):156-164. https://doi. org/10.1002/jbm.a.31763

Rowsell JLC, Eckert J, Yaghi M (2005) Characterization of H2 binding sites in prototypical metal-organic frameworks by inelastic neutron scattering. J Am Chem Soc 127(42):14904-14910

Ruyra A, Yazdi A, Espín J (2015) Synthesis, culture medium stability, and in vitro and in vivo zebrafish embryo toxicity of metal-organic framework nanoparticles. Chemistry 21:2508-2518. https://doi. org/10.1002/chem.201405380

Sabbatini N, Guardigli M, Lehn JM (1993) Luminescent lanthanide complexes as photochemical supramolecular devices. Coord Chem Rev 123(1-2):201-228

Sagar TP, Shah P (2014) Adsorptive removal of hazardous waste materials using metal-organic frameworks. In: International conference on multidisciplinary research \& practice, vol I, Issue VIII, IJRSI ISSN 2321-2705

Sajid M (2016) Toxicity of nanoscale metal organic frameworks: a perspective. Environ Sci Pollut Res. https://doi.org/10.1007/s1135 6-016-7053-y

Sajid M, Ilyas M, Basheer C (2015) Impact of nanoparticles on human and environment: review of toxicity factors, exposures, control strategies, and future prospects. Environ Sci Pollut Res 22:41224143. https://doi.org/10.1007/s11356-014-3994-1

Senkovska I, Kaskel S (2008) High pressure methane adsorption in the metal-organic frameworks $\mathrm{Cu}_{3}$ (btc) ${ }_{2}, \mathrm{Zn}_{2}$ (bdc) 2dabco, and $\mathrm{Cr}_{3} \mathrm{~F}\left(\mathrm{H}_{2} \mathrm{O}\right)_{2} \mathrm{O}(\mathrm{bdc})_{3}$. Microporous Mesoporous Mater 112(1-3): 108-115

Shooto ND, Dikio ED, Wankasi D, Sikhwivhilu L (2015) Synthesis, morphology and lead ion adsorption properties of metal organic frameworks of copper and cobalt. Chem Sci J 6:113. https://doi. org/10.4172/2150-3494.1000113

Song XQ, Liu WS, Don W, Wang YW, Zheng JR, Zang ZP (2008) "Structure variation and luminescence properties of lanthanide complexes incorporating a naphthalene-derived chromophore featuring salicylamide pendant arms. Eur J Inorg Chem 2008(11):1901-1912

Suparna R, Anantharaman P (2017) Heavy metals accumulation of different parts of Turbinaria spp. along the Olaikuda Coast, Rameshwaram, Tamilnadu, India. Int Adv Res J Sci Eng Technol 4(3):99-102

Tamames-Tabar C, Cunha D, Imbuluzqueta E (2014) Cytotoxicity of nanoscaled metal-organic frameworks. J Mater Chem B 2:262271. https://doi.org/10.1039/C3TB20832J

Tella AC, Owalude SO (2014) A Green route approach to synthesis of $\mathrm{Ni}(\mathrm{II})$ and $\mathrm{Zn}(\mathrm{II})$ templated metal-organic frameworks. J Mater Sci 49:5635-5639

Tella AC, Adediran GO, Mohammed HA (2007) Adsorption of Pb, $\mathrm{Cd}, \mathrm{Zn}, \mathrm{Cu}$ and $\mathrm{Hg}$ ions on formaldehyde and pyridine modified bean husks. J Appl Sci Environ Manag 11(2):153-158. www.bioli ne.org.br/ja

Tella AC, Owalude SO, Ojekanmi CA, Oluwafemi OS (2014) Synthesis of copper-isonicotinate Metal-organic Frameworks simply by

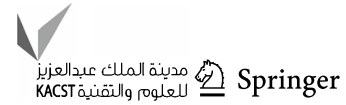


mixing solid reactants and investigation of its adsorptive properties in the removal of fluorescein dye. New J Chem 38:4494-4500

Tella AC, Ameen OA, Ajibade PA, Alimi LO (2015) Template metalorganic frameworks: solvent-free synthesis, characterization and powder X-ray diffraction studies of [Cu(NO3)2(bipy)2] (py)2. J Porous Mater 22(5):1599-1605

Tella AC, Olawale MD, Neuburger M, Obaleye JA (2017a) Synthesis and Crystal structure of Cd-based metal-organic framework for removal of methyl-orange from aqueous solution. J Solid State Chem 255:157-166

Tella AC, Oladipo AC, Adeyemi OG, Oluwafemi OS, Oguntoye SO, Alimi LO, Ajayi JT, Degni SK (2017b) Solid state synthesis, spectroscopic and X-ray studies of metal complexes of 2-picolinic acid and vapochromic behavior of [Co(Pic)2(H2O)2].2H2O. Solid State Sci 68:1-9

Tella AC, Mehlana G, Alimi LO, Bourne SA (2017c) Solvent-free synthesis, characterization and solvent-vapor interaction of zinc (II) and copper (II) coordination polymers containing nitrogendonor ligands. Zeitschrift fur anorganishe und allgemeine chemie (ZAAC) 64:523-530

Tella AC, Williams FE, Adeyemi OG, Alimi LO, Olatunji SJ (2017d) Development of zinc and copper-carboxylate metal-organic frameworks (MOFs) as potential drug carriers. Niger J Pharm 51(1):49-57

Tella AC, Owalude SO, Olatunji SJ, Adimula VO, Elaigwu SE, Alimi LO, Ajibade PA, Oluwafemi OS (2018) Synthesis of zinc-carboxylate metal-organic frameworks for the removal of emerging drug contaminant (amodiaquine) from aqueous solution. J Environ Sci 64:264-275
United Nations Environmental Protection/Global Program of Action (2004) Why the marine environment needs protection from heavy metals, Heavy Metals 2004, UNEP/GPA Coordination Office. http://www.oceansatlas.org/unatlas/uses/uneptextsph/waste sph/2602gpa. Accessed 30 Mar 2004

Vasconcelos IB, da Silva TG, Militão GCG (2012) Cytotoxicity and slow release of the anti-cancer drug doxorubicin from ZIF-8. RSC Adv 2:9437. https://doi.org/10.1039/c2ra21087h

Wang Z, Cohen SM (2009) Postsynthetic modification of metalorganic frameworks. Chem Soc Rev 38:1315-1329. https://doi. org/10.1039/B802258P

World Health Organization (WHO) (2011) Guildelines for drinkingwater quality, 4th edn. WHO

Wu Y-N, Zhang B, Li F, Zhu W, Xu D, Hannam P, Li G (2012) Electrospun fibrous mats as a skeleton for fabricating hierarchically structured materials as sorbents for $\mathrm{Cu}^{2+}$. J Mater Chem 22:5089-5097

Yang SJ, Kim T, Im JH (2012) MOF-derived hierarchically porous carbon with exceptional porosity and hydrogen storage capacity. Chem Mater 24(3):464-470

Zhao D, Yuan DQ, Zhou HC (2008) The current status of hydrogen storage in metal-organic frameworks. Energy Environ Sci 1:222235. https://doi.org/10.1039/b808322n

Publisher's Note Springer Nature remains neutral with regard to jurisdictional claims in published maps and institutional affiliations 